\title{
Physicochemical evaluation and fatty acids profile of broiler chicken fed broiler diets containing barley brewer (Hordeum vulgare)
}

\author{
Avaliação físico-química e perfil de ácidos graxos da carne de frangos de corte \\ alimentados com rações contendo cevada cervejeira (Hordeum vulgare)
}

\author{
Daiana NOVELLO ${ }^{1 *}$, Ricardo Alves da FONSECA ${ }^{2}$, \\ Marise Aparecida Rodrigues POLLONIO ${ }^{3}$, Priscilla FRANCESCHINI ${ }^{4}$
}

\begin{abstract}
The aim of this study was to analyze the chemical composition and the fatty acids (FA) profile of broiler chicken (breast and thigh/on-thigh) fed diets containing 10 and $20 \%$ of barley and a control diet. The FAs were evaluated by gas chromatography. There was not a significant difference $(p>0.05)$ in the breast chemical composition. In the thigh/on-thigh cut, the ration containing $20 \%$ of barley reduced the ashes $(\mathrm{p}<0.05)$. Regarding the saturated FA composition, only the breast myristic acid treated with $10 \%$ of barley was reduced $(p<0.05)$. None of the diets influenced the polyunsaturated (PUFA) and monounsaturated (MUFA) FA's content ( $p>0.05$ ). As for the $\omega 6 / \omega 3$ ratio, the highest one was observed in the $20 \%$ barley fed animals, in both cuts, being considered the worst quality. It can be concluded that the $20 \%$ barley ration was worse than the others and the $10 \%$ barley ration was better than the control ration, especially when considering the saturated FA quantity that was reduced.
\end{abstract}

Keywords: broiler chicken; barley brewer; fatty acids profile.

\section{Resumo}

Objetivou-se analisar a composição química e perfil de ácidos graxos (AG) da carne dos frangos (peito e coxa/sobrecoxa) alimentados com rações contendo 10 e $20 \%$ de cevada e ração controle. Os AG foram avaliados por cromatografia gasosa. Não houve diferença significativa ( $\mathrm{p}>0,05)$ na composição química da carne do peito. Na coxa/sobrecoxa, a dieta com $20 \%$ de cevada diminuiu as cinzas $(\mathrm{p}<0,05)$. Em relação à composição de $\mathrm{AG}$ saturados, apenas o ácido mirístico do peito tratado com $10 \%$ de cevada foi diminuído $(\mathrm{p}<0,05)$. Nenhuma dieta influenciou no teor de AG monoinsaturados e poli-insaturados ( $\mathrm{p}>0,05)$. Quanto à relação $\omega 6 / \omega 3$, a maior foi observada nos animais alimentados com $20 \%$ de cevada, em ambos os cortes, sendo considerada a de pior qualidade. Conclui-se que a ração com $20 \%$ de cevada foi pior do que as demais e a com $10 \%$ de cevada foi melhor que a ração testemunha, principalmente avaliando-se a quantidade de AG saturados que foi diminuída.

Palavras-chave: frangos de corte; cevada cervejeira; perfil de ácidos graxos.

\section{Introduction}

In Brazil, poultry cutting is one of the most advanced technological activities with productivity levels similar to those of most developed countries, which contributes significantly to the supply of low cost animal protein and generates wealth to the country (BERTOGLIO, 2006).

The West Region of Parana State concentrates a significant number of agribusiness intended for the broiler chicken production, slaughter, and commercialization (RAFAELLI et al., 2001). These industries usually produce and commercialize poultry rations, and they work through an integration system with numberless producers (PINOTTO et al., 2006). On the other hand, the food industry is highly competitive and the manufacturers are continuously trying to increase their market niche and profits. Therefore, they must ensure that their products are of high quality and affordable, and that they are safe and nutritious. Accordingly, these industries must have an effective control of their activities since they reflect directly in the market (SANTINI et al., 2006). However, with all the knowledge accumulated so far, it is still difficult to share the poultry nutritional evolution knowledge with the genetic advances in the management practices, with the sanitary problems, with the environmental variables, and also with the market competitiveness aspects (JUNIOR et al., 2007).

Meat usually contains from 60 to $80 \%$ of water and 15 to $25 \%$ of protein, and the rest contains mostly fats, salts, pigments, and vitamins (LAWRIE, 2004). Meat products are the preferred

\footnotetext{
Recebido para publicação em $7 / 8 / 2007$

Aceito para publicação em 8/7/2009 (002743)

Departamento de Nutrição, Universidade Estadual do Centro-Oeste - UNICENTRO, Rua Camargo Varela de Sá, 03, Bairro Vila Carli, CEP 85040-080, Guarapuava - PR,

E-mail: nutridai@pop.com.br

2 Ciências e Letras de Paranaguá, Faculdade Estadual de Filosofia, Universidade Estadual do Paraná

${ }^{3}$ Departamento de Tecnologia de Alimentos, Faculdade de Engenharia de Alimentos - FEA, Universidade Estadual de Campinas - UNICAMP

4 Universidade Estadual do Centro-Oeste - UNICENTRO

${ }^{*}$ A quem a correspondência deve ser enviada
} 
food by most consumers, but they are often mentioned as food with high contents of cholesterol, fat, and saturated FAs and low levels of unsaturated FAs (BRAGAGNOLO, 2001). A significant number of studies in humans and animals were accumulated over the years attesting the monounsaturated fatty acids (MUFA) neutrality in the blood cholesterol levels elevation. Most current studies show that when replacing the saturated FA by MUFA the LDL's levels decrease while HDL remains unaffected (HULBERT et al., 2005). PUFAs are naturally beneficial since they reduce thrombocytes and triglycerides aggregations and, consequently, the risk of heart diseases (MAHAN; ARLIN, 2005). PUFAs are considered essential and since they are not naturally produced by the organism, they should be ingested with the daily food supply, which are omega $6(\omega-6,18: 2)$ and omega 3 ( $\omega-3,18: 3)$ (MAHAN; ARLIN, 2005).

Besides the poultry meat quality, there has been nowadays a great demand for the substitution of soybean and corn by lower cost options in the poultry feeding. This alternative demands the evaluation not only of the income, but also for the quality of the meat produced (SOUZA-SOARES; SIEWERDT, 2005). The use of such foods in the animal ration formulation is regionalized. In Brazil, barley is produced in the Southern States, which in 2005 produced 235.150 ton (IBGE, 2003). Almost $100 \%$ of the Brazilian barley production is used to make malt. The Center-West Region of Parana shelters one of the largest Malting Companies in the country, which provides a large quantity of brewing barley to the market. However, further research is needed so that this kind of food could be better characterized by biological tests to identify the appropriate levels to be included in the animal ration, besides the possible influence in the quality of these animal carcasses fed with those products (AGRÁRIA, 2007).

The content of crude protein (CP) of barley is higher than the corn and less than that of wheat, and it presents lower quality and lower digestibility (EMBRAPA, 1999; DALE, 1996; FEED, 1997). The energy content level is somewhat lower than that of wheat and around 10\% lower than the corn, and also it has minor digestibility due to the higher fiber content (EMBRAPA, 1999; DALE, 1996; FEED, 1997). The addition of elevated barley levels in the rations can be limited by its content of crude fiber, and it usually demands energy supplementation. Barley can be polished to remove its outer husk obtaining a product with lower fiber content and higher nutrients concentration, being, however, unusual and cost limited (ZARDO; LIMA, 1999).

Knowing the importance of using nutritional richer food with lower cost in monogastric nutrition, the purpose of the present study was to evaluate the effect of barley use on the chemical composition and in the FAs profile of broiler chicken.

\section{Materials and methods}

\subsection{Animals and rations}

The experiments were conducted in the Animal Nutrition Laboratory of the Health Science Center, Department of Nutrition of Parana Center-West State University -
UNICENTRO, in Guarapuava - PR, from January to December 2004. Three treatments were evaluated with five repetitions and ten broilers for each experimental unit with a total of 150 male broiler chickens from commercial hybrid lineage. The animals were lodged in cages, for a period of 42 days old with an initial weight of $38 \mathrm{~g}$ (the first day of life). The environment was acclimatized during the whole experimental period for the bigger animals' thermal comfort.

The experimental treatment diets were: Treatment Diet 1 - Control Ration (control treatment); Treatment Diet 2 - 10\% Barley Ration; Treatment Diet 3-20\% Barley Ration. Both levels of the food tested were included in the reference ration (Table 1) and were calculated according to the reports of Rostagno et al. (2000). The three experimental rations were isocaloric and isoproteic. During the experimental period, both the ration and water were provided at will. Table 2 indicates the fatty acids profile of the rations used as experimental treatments.

Table 1. Proximate composition of treatment diets (Broiler Chicken).

\begin{tabular}{|c|c|c|c|}
\hline Ingredients & $\begin{array}{c}\text { Amount } \\
(\%)\end{array}$ & $\begin{array}{c}\text { Control } \\
\text { barley } 10 \% \\
\end{array}$ & $\begin{array}{c}\text { Barley } \\
20 \% \\
\end{array}$ \\
\hline Corn & 59.30 & 48.63 & 36.69 \\
\hline Soybean meal $45 \%$ & 34.33 & 34.29 & 34.49 \\
\hline Barley & - & 10.00 & 20.00 \\
\hline Soybean oil & 1.98 & 2.69 & 4.44 \\
\hline Dicalcium phosphate & 1.78 & 1.83 & 1.88 \\
\hline Limestone & 0.96 & 0.91 & 0.87 \\
\hline Rice rind & 0.50 & 0.50 & 0.50 \\
\hline Salt & 0.44 & 0.45 & 0.46 \\
\hline DL - Methionine & 0.23 & 0.24 & 0.24 \\
\hline Px Vitamin - Broiler ${ }^{1}$ & 0.20 & 0.20 & 0.20 \\
\hline L - lysine HCL & 0.18 & 0.16 & 0.14 \\
\hline Px mineral - Broiler ${ }^{2}$ & 0.10 & 0.10 & 0.10 \\
\hline Total & 00.00 & 100.00 & 100.00 \\
\hline \multicolumn{4}{|l|}{ Calculated composition } \\
\hline Met. energy (kcal/kg) & $2,950.00$ & $2,950.00$ & $2,950.00$ \\
\hline Crude protein & 21.04 & 21.04 & 21.04 \\
\hline Calcium & 0.94 & 0.94 & 0.94 \\
\hline Available phosphorus & 0.44 & 0.44 & 0.44 \\
\hline Total lysine & 1.24 & 1.24 & 1.24 \\
\hline Total methionine and cystine & 0.88 & 0.88 & 0.88 \\
\hline Total methionine & 0.55 & 0.55 & 0.55 \\
\hline Total thryptophan & 0.26 & 0.26 & 0.26 \\
\hline Sodium & 0.22 & 0.22 & 0.22 \\
\hline Potassium & 0.81 & 0.78 & 0.74 \\
\hline Linoleic acid & 2.44 & 2.63 & 3.34 \\
\hline Crude fiber & 3.39 & 6.82 & 7.39 \\
\hline Chlorine & 0.30 & 0.30 & 0.30 \\
\hline
\end{tabular}


Table 2. Chemical analysis of the diets evaluated in relation to the saturated, monounsaturated, and polyunsaturated FAs (g.100 g $\left.{ }^{-1}\right)$.

\begin{tabular}{lccc}
\hline \multicolumn{1}{c}{ Fatty acid } & Control diet & Barley 10\% & Barley 20\% \\
\hline Saturated & & & \\
C14:0 Myristic acid & 0.18 & 0.03 & 0.06 \\
Arachidic & NA & 0.41 & 0.44 \\
C16:0 Palmitic acid & 11.23 & 10.11 & 12.27 \\
C18:0 Stearic acid & 3.49 & 3.46 & 3.64 \\
Total & 14.90 & 14.01 & 16.35 \\
Monounsaturated & & & \\
C18:1, $\omega-9$ cis oleic acid & 28.01 & 25.07 & 24.85 \\
C20:1, $\omega-9$ cis & 0.17 & 0.41 & 0.82 \\
11 - eicosenoic acid & & & \\
MUFAs total & 28.18 & 25.48 & 24.85 \\
Polyunsaturated & & & \\
C18:2, $\omega-6$ linoleic acid & 51.17 & 52.32 & 53.40 \\
C18:3, $\omega-3 \alpha$-Linolenic & 3.67 & 4.67 & 5.28 \\
acid & & & \\
PUFAs total & 54.84 & 56.99 & 58.68 \\
$\omega 6 / \omega 3$ ratio & 13.90 & 11.20 & 10.11 \\
Poly/saturated relation & 3.68 & 4.07 & 3.59 \\
\hline$*$ The analyses are expressed on a dry & &
\end{tabular}

${ }^{*}$ The analyses are expressed on a dry matter basis; and NA - not available.

\subsection{Slaughter and samples preparation}

At the end of the experimental period, the broiler chickens were weighed and a medium body weight animal was then separated for each repetition. After six hours of fasting, they were put to sleep. Soon after the slaughter, the broiler chickens were frozen at $-18{ }^{\circ} \mathrm{C}$ temperature until the chemical analyses. For these analyses, the carcasses were defrosted in a refrigerator with temperature around $10^{\circ} \mathrm{C}$ for 24 hours. Then, all the visible fat and skin were eliminated from the breast and thigh/on-thigh samples. The meat was grinded in a food processor until a pasty matter was obtained. The moisture (dry matter) and ashes (mineral matter) analyses were conducted in the Engineering Processes Laboratory at the UNICENTRO Food Engineering Department in Guarapuava-PR. The remaining samples were placed in labeled trays and dried in an oven with circulating air at $55^{\circ} \mathrm{C}$ for 24 hours to remove the moisture. The dry samples were then sent to EMBRAPA Swine and Poultry Physical Chemistry Analyses Laboratory, located in the city of Concordia, Santa Catarina State, where the crude protein, ethereal extract and FAs profile analyses were performed.

\subsection{Physicochemical analysis}

For the chemical analysis of the meat, the following methodologies were used: for moisture and ashes determination the procedure according to Adolfo Lutz Institute (1985) in triplicate was used, and the total protein content was quantified in duplicate using the classical Micro-Kjedahl method (AOAC, 1995a).

\subsection{Fatty acids analysis}

The FAs analysis was accomplished in dry matter and in duplicate using the Hartman and Lago (1986) methodology.
The FAs identification method was the comparison between the triglycerides methyl ester samples and triglycerides from authentic standards (methyl esters Sigma). The total lipid analysis was accomplished in duplicate according to AOAC (1995b) methodology.

\subsection{Statistical analysis}

The statistical data were analyzed using SISVAR software (FERREIRA, 1999) considering a 5\% significant level using Tukey's Test.

\section{Results and discussion}

Table 3 describes the chemical analysis results for the broiler chicken submitted to the experimental treatments.

As observed in Table 3 , no significant different values were found ( $p>0.05)$ in the broiler chicken breast chemical analysis fed with the three experimental treatments. But, for the thigh/ on-thigh broiler chicken, only the ashes showed significant difference $(\mathrm{p}<0.05)$ once the rations presented an increase of 10 and $20 \%$ of barley concentration. In this same cut, even without significant difference $(\mathrm{p}=0.0908)$ in the ethereal extract (EE) contents from the experimental diets, an EE contents reduction in the proportion of 23.94 and $21.57 \%$ on diets with 10 and $20 \%$ of barley, respectively regarding the control ration was verified, and a quality improvement was demonstrated in the meat treated with these rations.

Torres et al. (2000) accomplished a centesimal composition analysis from broiler chicken collected from local markets in the city of Sao Paulo, Brazil. Regarding moisture, it the value of $70.51 \mathrm{~g} .100 \mathrm{~g}^{-1}$ was found for broiler chicken thigh, which is less than that reported in this research. For the broiler chicken breast, the value found was $73.81 \mathrm{~g} .100 \mathrm{~g} \mathrm{~g}^{-1}$, which is very similar to the one obtained in the present study. Evaluating the ashes amount in the cuts, the authors obtained $0.78 \mathrm{~g} .100 \mathrm{~g}^{-1}$ for the thigh and $1.10 \mathrm{~g} .100 \mathrm{~g}^{-1}$ for the breast; therefore, the treatments with reference ration and that containing $10 \%$ barley, from the breast and thigh/on-thigh broiler chicken evaluated in this study, presented higher values, except from the ration containing 20\% barley that has obtained very similar values in both cuts.

Van Heerden et al. (2002) studied the chemical composition of broiler chickens sold in South Africa's trade and they reported lower values for thigh/on-thigh humidity, equal values for the breast, higher values regarding the fat and protein in the breast and thigh, and equal values regarding the ashes content in both cuts when compared to this study.

In comparison with values in the USDA Food Composition Table (1999), the total contents of lipids in this research regarding the white meat presented lower values than those shown in the Table that contains $1.65 \mathrm{~g} .100 \mathrm{~g}^{-1}$. The protein quantity presented by the USDA Table (1999) is $23.20 \mathrm{~g} .100 \mathrm{~g}^{-1}$, and this value is higher than the ones obtained in this study. In raw thigh, it was related in Table USDA $4.31 \mathrm{~g} .100 \mathrm{~g}^{-1}$ of lipids, showing very similar results to the current study, and, $20.08 \mathrm{~g} .100 \mathrm{~g}^{-1}$ of proteins, this is a higher value when compared to this study. Regarding moisture and ashes, in both evaluated 
cuts, the results are in agreement with this study. When the results were compared to the Brazilian Food Composition Table - TACO (2004), it shows higher values of lipids and protein for the broilers breast and the thigh/on-thigh. Regarding humidity and ashes, the Table shows similar values to the breast and thigh/on-thigh portion as those reported in this study.

Table 4 demonstrates the results obtained for the breast and thigh/on-thigh meat, respectively in relation to the saturated FA.

Table 4 evidences that there was significant difference $(\mathrm{p}<0.05)$ between the saturated myristic FA in the analyzed broiler chicken breast, and that the treatment with $10 \%$ of barley reduced the quantity of this acid regarding the control diet. This reduction is considered beneficial once this acid is considered hyperlipidemic (KEYS et al., 1965). In addition, the hypercholesterolemic effect of the saturated FAs, as Farfan (1996), is associated with the lauric acid (C12:0), myristic acid (C14:0), and palmitic acid (C16:0).

Qureshi et al. (1980b) and Fonseca (1996) noted an expressive reduction in the liver size when barley crushing grains were used as basic ingredients in broiler chicken rations. The chemical content of the food influences the weight gain of the poultry, mainly, with the presence of non-starch polysaccharides (NSP) such as the $\beta$-glucan barley. In addition to the liver size change due the presence of this anti-nutritional factor, there is also a basic difference between the metabolism in mammals and in poultry regarding the the occurrence of lipogenesis. In mammals, lipogenesis occurs, practically, in adipose tissue; however, in poultry it is processed in liver cells. In poultry, only after this physiological mechanism the distribution of lipids to the adipose tissue is done.

The effect of Barley used in food when compared with corn in the broiler chicken lipid metabolism has been described by many researchers (QURESHI et al., 1980a). A significant decrease in the cholesterol biosynthesis occurs when barley it is used on diets, and this effect is followed by a great increase in the fatty acid biosynthesis (BURGER et al., 1982).

The different components of barley grains and their quantities produce different effects in the organism. Therefore, the chemical composition variation of certain foods can define their use. Thus, the NSP has a great control over the poultry diet interfering in the intestinal absorption of lipids, reducing the abdominal fat (FRANCESCH et al., 1994), and it can also reduce the diet efficiency and decrease the digestibility of many nutrients (BRUFAU et al., 1994). Camiruaga et al. (2001) added that there is enough evidence to conclude that the NSP solubility and viscosity can influence the broiler chicken digestion of fat, protein, and starch.

The NSPs (arabinoxylans, D-xylan, $\beta$-glucans, D-mannans, galactomannans, xyloglucans, ramnogalacturonana and pectics substances, among others) present on diets are not digested due their beta links because there is a lack of intestinal endogenous enzymes in poultry, and also interfering in the use of all nutrients due the gel formation and viscosity during digestion. Also, the

Table 3. Chemical analysis of the broilers meat (breast and thigh/on-thigh) fed treatment diets in relation to Humidity, Ashes, Crude Protein (CP) and Ether Extract (EE).

\begin{tabular}{|c|c|c|c|c|c|c|c|c|c|c|c|c|}
\hline \multirow[t]{2}{*}{ Breast } & \multicolumn{2}{|c|}{ Humidity (\%) } & \multicolumn{2}{|c|}{ Ashes (\%) } & \multicolumn{2}{|c|}{$\mathrm{CP}^{*}(\%)$} & \multicolumn{2}{|c|}{$\mathrm{EE}^{*}(\%)$} & \multicolumn{2}{|c|}{$\mathrm{CP}^{* \star}(\%)$} & \multicolumn{2}{|c|}{$\operatorname{EE}^{\star *}(\%)$} \\
\hline & Breast & $\begin{array}{l}\text { Thigh/ } \\
\text { on-thigh }\end{array}$ & Breast & $\begin{array}{l}\text { Thigh/ } \\
\text { on-thigh }\end{array}$ & Breast & $\begin{array}{l}\text { Thigh/ } \\
\text { on-thigh }\end{array}$ & Breast & $\begin{array}{c}\text { Thigh/ } \\
\text { on-thigh }\end{array}$ & Chest & $\begin{array}{l}\text { Thigh/ } \\
\text { on-thigh }\end{array}$ & Breast & $\begin{array}{l}\text { Thigh/ } \\
\text { on-thigh }\end{array}$ \\
\hline Treatment 1 & $73.49^{\mathrm{a}}$ & $75.62^{\mathrm{a}}$ & $1.34^{\mathrm{a}}$ & $1.07^{\mathrm{b}}$ & $84.97^{\mathrm{a}}$ & $82.94^{a}$ & $4.65^{\mathrm{a}}$ & $20.72^{\mathrm{a}}$ & $21.48^{\mathrm{a}}$ & $15.99^{\mathrm{a}}$ & $1.24^{\mathrm{a}}$ & $5.08^{\mathrm{a}}$ \\
\hline Treatment 2 & $74.23^{\mathrm{a}}$ & $74.99^{\mathrm{a}}$ & $1.21^{\mathrm{a}}$ & $1.11^{\mathrm{b}}$ & $82.92^{\mathrm{a}}$ & $81.74^{\mathrm{a}}$ & $3.22^{\mathrm{a}}$ & $15.76^{\mathrm{a}}$ & $20.68^{\mathrm{a}}$ & $17.22^{\mathrm{a}}$ & $0.83^{\mathrm{a}}$ & $3.94^{\mathrm{a}}$ \\
\hline Treatment 3 & $74.81^{\mathrm{a}}$ & $76.23^{\mathrm{a}}$ & $1.09^{\mathrm{a}}$ & $0.80^{\mathrm{a}}$ & $82.80^{\mathrm{a}}$ & $80.06^{\mathrm{a}}$ & $4.34^{\mathrm{a}}$ & $16.25^{\mathrm{a}}$ & $19.97^{\mathrm{a}}$ & $15.94^{\mathrm{a}}$ & $1.08^{\mathrm{a}}$ & $3.86^{\mathrm{a}}$ \\
\hline $\begin{array}{l}\text { Standard } \\
\text { Error }\end{array}$ & 0.85 & 1.07 & 0.10 & 0.06 & 0.54 & 0.89 & 0.65 & 1.65 & 0.77 & 0.66 & 0.17 & 0.52 \\
\hline Coefficient & 2.00 & 2.46 & 14.53 & 9.93 & 1.12 & 1.90 & 27.80 & 16.23 & 6.41 & 6.94 & 27.85 & 20.95 \\
\hline
\end{tabular}

of variation

The values in the columns followed by different letters differ significantly according to the Tukey test $(\mathrm{p}<0.05)$; ${ }^{\star}$ the analyses are expressed on a dry matter basis; and ${ }^{\star *}$ the analyses are expressed on a natural matter basis.

Table 4. Chemical analysis of the evaluated breast and thigh/on-thigh broiler chickens in relation to the saturated FA ( $\left.\mathrm{g} .100 \mathrm{~g}^{-1}\right)$.

\begin{tabular}{|c|c|c|c|c|c|c|c|c|c|c|}
\hline \multirow[t]{2}{*}{ Fatty acid } & \multicolumn{2}{|c|}{ Treatment 1} & \multicolumn{2}{|c|}{ Treatment 2} & \multicolumn{2}{|c|}{ Treatment 3} & \multicolumn{2}{|c|}{ Standard error } & \multicolumn{2}{|c|}{ Coefficient of variation } \\
\hline & Breast & $\begin{array}{l}\text { Thigh/ } \\
\text { on-thigh }\end{array}$ & Breast & $\begin{array}{l}\text { Thigh/ } \\
\text { on-thigh }\end{array}$ & Breast & $\begin{array}{l}\text { Thigh/ } \\
\text { on-thigh }\end{array}$ & Breast & $\begin{array}{l}\text { Thigh/ } \\
\text { on-thigh }\end{array}$ & Breast & $\begin{array}{l}\text { Thigh/ } \\
\text { on-thigh }\end{array}$ \\
\hline $\begin{array}{l}\text { C14:0 } \\
\text { Myristic acid }\end{array}$ & $0.020^{\mathrm{b}}$ & $0.090^{\mathrm{a}}$ & $0.010^{\mathrm{a}}$ & $0.073^{\mathrm{a}}$ & $0.013^{\mathrm{ab}}$ & $0.077^{\mathrm{a}}$ & 0.000 & 0.009 & 23.080 & 19.980 \\
\hline $\begin{array}{l}\text { C16:0 } \\
\text { Palmitic acid }\end{array}$ & $0.880^{\mathrm{a}}$ & $4.203^{\mathrm{a}}$ & $0.877^{\mathrm{a}}$ & $3.183^{\mathrm{a}}$ & $0.933^{\mathrm{a}}$ & $3.147^{\mathrm{a}}$ & 0.099 & 0.395 & 19.050 & 19.510 \\
\hline $\begin{array}{l}\text { C18:0 } \\
\text { Stearic acid }\end{array}$ & $0.297^{\mathrm{a}}$ & $1.217^{\mathrm{a}}$ & $0.253^{\mathrm{a}}$ & $0.973^{\mathrm{a}}$ & $0.270^{\mathrm{a}}$ & $0.977^{\mathrm{a}}$ & 0.030 & 0.113 & 19.090 & 18.560 \\
\hline
\end{tabular}

*The values in the columns followed by different letters differ significantly among themselves according to the Tukey test ( $\mathrm{p}<0.05$ ); and ${ }^{\star *}$ the analyses are expressed on a dry matter basis. 
intestinal viscosity and biliary salts form a chemical complex that reduces the emulsification of fats (TORRES, 2003), and, consequently, the cholesterol and the reabsorption of lipids.

In Crespo and Esteve-Garcia's (2001) study, broiler chicken, which received experimental wheat diets (also with high content of NSP), glutenose, and soybean meal complemented with $10 \%$ of sunflower oil, with reference to dry matter, presented the following results for thigh and breast, 31.4 and $27.0 \mathrm{mg} \cdot \mathrm{g}^{-1}$ of $18: 2$, respectively.

Other explanations must be considered when barley is used since the conjugated linoleic acid - CLA (18:2 c-9, t-11) present in the cereal, discovered in 1979, can be found mainly in eggs, dairy, and meats as a derived lipid

Recently, researchers have been exploring the possibility of increasing the beneficial effects of these animal products through diet manipulation. Besides, those products have received considerable attention because they have 19 biological properties related to health including body fat decrease, antidiabetic agent effect, reduction of the development of atherosclerosis, and others (CHOUINARD et al., 1999).

CLA is the generic term of a group of octadecenoic acids which are positional and geometric isomers of the linoleic acid (C18:2) when the double bonds are separated by single carboncarbon bonds instead of a methylene group; two of which (cis-9, trans-11 and trans-10, cis-12 CLA) have biological properties (PARIZA et al., 2001).

In Brazil, few studies have been carried out to evaluate the nutrition effects on CLA contents in meat. In some countries, the results emphasize that CLA concentration in uncooked meat of animals fed with barley presented $1.7-1.8 \mathrm{mg} \cdot \mathrm{g}^{-1}$ of fat content (MIR et al., 2004). Higher levels of CLA were found in studies in which the animals were fed with grasses. They were summarized by Mir et al. (2004).

At first, these results can be considered contradictory, because grasses, barley for example, are not great sources of lipids, like the oleaginous. However, it should not be forgotten the fact that grasses are rich in galactolipids and they have the linoleic acid as main FA unsaturated. Since there are few studies available in Brazil, manly on poultry, one may cite the cattle case, in which C18:2, cis-9, trans-11 is obtained from grasses. Like the linoleic acid, the linoleic acid biohydrogenation leads to formation of the intermediary C18:1, trans-11, known as the vaccenic acid (LADEIRA; OLIVEIRA, 2006). The effect of dietary CLA present in barley and its byproduct when added to the diets is still weak as well as its effects on the meat and carcass of broiler chickens.

The increase and decrease of fat deposition might be connected to lipolysis or lipogenesis, respectively, which are probably also connected to the reduction or increase of muscle lipid deposition depending on the barley levels added to the diets.

One fully studied effect is the reduction in the cholesterol levels and the serum low density lipoprotein (LDL) since it is known that the reduction of about $5-15 \%$ is obtained with guar gum, pectin, psilio, oat fiber, and $\beta$-glucans with doses of
3-5 g/day. It is important to note that barley, as well as oat, is also a rich cereal in $\beta$-glicans or $\beta$-glucans and, therefore, the mechanism of action in lipid control is similar to the oat's.

The effect is greater in people with higher blood cholesterol (RUBERFROID, 1993; ANDERSON; HANNA, 1999). It was suggested that the fibers which reduce the blood cholesterol do it connecting the bile acids and increasing their excretion, exhausting inhibiting its concentration in the serum cholesterol (NEVES, 1997; NESTLÉ NUTRITION SERVICES, 2000). However, this is a controversial issue because there are other possible explanations, like, for example, the one that the viscosity of the soluble fibers can interfere in lipids absorption. The soluble fibers are almost completely fermented in the colon producing short chain fatty acids which can inhibit the hepatic synthesis of cholesterol and increase the LDL-cholesterol clearance (NEVES, 1997).

In the evaluation of thigh/on-thigh cut, no significant difference between the treatments analyzed in relation to the FAs saturated was observed. Regarding the FAs saturated, no statistical difference between the treatments for breast meat or thigh/on-thigh was found.

Barley levels in the treatments in this study presented adverse responses. Regardless the results for the incorporation of barley into diets, the poultry adipose tissue did not synthesize substantial amounts of fat, so it can be said that it was dependent on the fatty acids from digestion or those synthesized by the liver. This justifies the poultry the scarcity of adipose tissue, which occurs far from blood capillaries and is well vascularized. However, other diet factors can interfere in the fat acid saturated/ unsaturated relation, copper concentration for example. Copper can increase the tissue desaturase activity and decrease this relation. Other factors already described are the NSPs, which can influence fat and protein and starch digestion in broiler chickens; however, their effects are apparently mediated by the microbiota in short chain synthesis of fatty acids (CAMIRUAGA et al., 2001). The short chain fatty acid has up to 10 carbons in its structure and is denominated by butyric, isobutyric, propionic, acetic, valeric, and isovaleric.

This apparent contradiction in the results between the treatments that received 10 and $20 \%$ of barley incorporation with the increase of unsaturated FAs possibly happened due the volatile fatty acid synthesis in the large intestine. Moore et al. (1998), Behall et al. (2004), and Li et al. (2004) related that this phenomenon has an important activity in the physiology of the intestine, as the main source of energy, improves blood flow, increases water and sodium absorption and the hydrogen potential essential to intestinal trophism properties in glucose and cholesterol metabolism.

In a comparison with hens, Fonseca (1996) identified an inverse effect such as that which happened to cholesterol because the lipids showed a tendency of increasing in eggs of chicken fed with barley incorporation diets and supplemented with culture filtrate of Trichoderma viride that has a probiotics activity. Qureshi et al. (1984) classified this kind of activity as the stimulus cause of lipogenic activity confirming what Camiruaga et al. (2001) found, described in the above paragraph. 
Although it was not the objective of this study, it is important to remind that steatorrhea happens in poultry frequently accompanied by a decrease in specific and total activities of pancreatic lipase, main fat digestive enzime, and bile salts decrease which are necessary both in digestion and in fat absorption resulting in hepatic steatosis (fatty liver).

Perez et al. (2002) stated that the studies which refer to fatty acids and cholesterol composition are contradictory in the literature. To Bragagnolo and Rodriguez-Amaya (2002), in order to keep the blood cholesterol low, the diet should be poor in total lipids, cholesterol, and saturated fatty acids. These authors also affirm that the Brazilian literature lacks data on animal cholesterol and fat acid levels.

Regarding saturated FA total, Bragagnolo and RodriguezAmaya (1992) found $0.84 \mathrm{~g} .100 \mathrm{~g}^{-1}$ in white meat and $2.18 \mathrm{~g} .100 \mathrm{~g}^{-1}$ in red meat. These values are, generally, lower than those obtained in this study.

When evaluating the chemical composition of FAs in chicken meat, Souza et al. (1999) found similar breast meat results for C14:0 and higher results for C16:0 and C18:0. For chicken thigh/on-thigh they found values lower values than C14:0 and C16:0 and similar to C18:0 when compared to the evaluated results in treated meat with control ration in this research. The kind and the amount of monounsaturated FAs evaluated can be observed in Table 5, respectively, for breast and thigh/on-thigh.

In Table 5 it can be observed no diet influence $(p>0.05)$ in monounsaturate contents, as in breast as thigh/ on-thigh from the analized chicken. Bragagnolo e Rodriguez-Amaya (1992), found as in white meat as in red meat lower MUFA values compared with this study.

Souza et al. (1999), evaluating chicken meat related to FAs composition, have verified in thigh and breast without skin, lower results of C16:1 and C18:1 when compared to this study, curiously the authors did not find in the analysis the FA C20:1, $\omega$-9. Van Heerden et al. (2002), who have studied the chemical composition of chicken sold in South Africa, observed that in breast the palmitoleic acid amount was very similar to this experiment and found lower values of oleic and cis-11-eicosenoic acid. In the thigh/on-thigh cut, all FAs analysed by the authors presented lower results than this study.

Table 6 presents the results related to the polyunsaturated FAs in breast and thigh/on-thigh meat, respectivly.

It can be observed in Table 6 that was not possible to change the PUFA FA profile $(p>0.05)$ because of the inclusion of different levels of FAs in the diets. These results are beneficial once according to González-Esquerra and Leeson (2000) and Bou et al. (2001), an increase in the level of polyunsaturated FAs in meat can emphasize the development of organoleptics properties and, mainly, an increase in the susceptibility to lipid oxidation in meat (CORTINAS et al., 2001; GRAU et al., 2001a, b). Some authors suggest that the lower fat quantity in chicken fed with polyunsaturated fat compared with those fed with saturated fat can be probably explained by an increase in the rate of lipid catabolism and by a decrease in the FAs synthesis (SANZ, 2000). This was not verified in the present study. Such discrepancy in the intramuscular fat content in the breast muscle must be due to many factors such as the analytical procedure for fat extraction from the sample.

Some recent studies show that the tissue fat content with treatments containing more polyunsaturated was lower when the lipid content was analyzed using the AOAC methodology (AOAC, 1995) suggesting that the FAs total content is an estimation of crude fat in higher polyunsaturated sample (VILLAVERDE et al., 2003). According to Pan and Storlien (1993) and López-Bote et al. (1997), generally, the change in FAs intramuscular fat composition is used mainly as cell membranes, and the cell has to keep the physical characteristics to ensure the flow and permeability that have different combinations. Those studies corroborate the present study since there was no change in the chicken PUFAs profile. Differences in FAs tissue profile may be assigned to different functions of FAs in this tissue or to the different phospholipids contents. The PUFAs are preferably incorporated in phospholipids (HULAN et al., 1988) and the phospholipids are present in a higher proportion in breasts than in thigh muscles (RATNAYAKE et al., 1989). The relations between different FAs families (PUFA, MUFA, Saturated) in diets and tissues were studied and the authors observed that the PUFA content in the chicken tissue depends mostly on diet FAs variation instead of SFA and MUFA contents in this

Table 5. Chemical analysis of the evaluated broiler chicken breast and thigh/on-thigh in relation to the monounsaturated FA ( $\mathrm{g} 100 \mathrm{~g}^{-1}$ ).

\begin{tabular}{|c|c|c|c|c|c|c|c|c|c|c|}
\hline \multirow[t]{2}{*}{ Fatty acid } & \multicolumn{2}{|c|}{ Treatment 1} & \multicolumn{2}{|c|}{ Treatment 2} & \multicolumn{2}{|c|}{ Treatment 3} & \multicolumn{2}{|c|}{ Standard error } & \multicolumn{2}{|c|}{ Coefficient of variation } \\
\hline & Breast & $\begin{array}{l}\text { Thigh/ } \\
\text { on-thigh }\end{array}$ & Breast & $\begin{array}{c}\text { Thigh/ } \\
\text { on-thigh }\end{array}$ & Breast & $\begin{array}{l}\text { Thigh/ } \\
\text { on-thigh }\end{array}$ & Breast & $\begin{array}{c}\text { Thigh/ } \\
\text { on-thigh }\end{array}$ & Breast & $\begin{array}{l}\text { Thigh/ } \\
\text { on-thigh }\end{array}$ \\
\hline $\begin{array}{l}\text { C16:1, } \omega-7 \text { cis } \\
\text { Palmitoleic acid }\end{array}$ & $0.197^{\mathrm{a}}$ & $1.077^{\mathrm{a}}$ & $0.167^{\mathrm{a}}$ & $0.820^{\mathrm{a}}$ & $0.200^{\mathrm{a}}$ & $0.810^{\mathrm{a}}$ & 0.031 & 0.095 & 28.460 & 18.310 \\
\hline $\begin{array}{l}\text { C18:1, } \omega-9 \text { cis } \\
\text { Oleic acid }\end{array}$ & $1.660^{\mathrm{a}}$ & $7.713^{\mathrm{a}}$ & $1.423^{\mathrm{a}}$ & $5.703^{\mathrm{a}}$ & $1.660^{\mathrm{a}}$ & $6.153^{\mathrm{a}}$ & 0.152 & 3.150 & 17.120 & 19.290 \\
\hline $\begin{array}{l}\text { C20:1, } \omega-9 \text { cis } \\
11-\text { cis - Eicosenoic } \\
\text { acid }\end{array}$ & $0.067^{\mathrm{a}}$ & $0.067^{\mathrm{a}}$ & $0.063^{\mathrm{a}}$ & $0.060^{\mathrm{a}}$ & $0.057^{\mathrm{a}}$ & $0.053^{\mathrm{a}}$ & 0.007 & 0.013 & 20.750 & 38.090 \\
\hline MUFAs total & $1.924^{\mathrm{a}}$ & $8.857^{\mathrm{a}}$ & $1.653^{\mathrm{a}}$ & $6.583^{\mathrm{a}}$ & $1.917^{\mathrm{a}}$ & $7.016^{\mathrm{a}}$ & 0.024 & 1.236 & 18.658 & 19.678 \\
\hline
\end{tabular}

${ }^{*}$ The values in the lines followed by different letters differ significantly among themselves according to the Tukey test ( $\left.\mathrm{p}<0.05\right)$; and ${ }^{* *}$ the analyses are expressed on a dry matter basis. 
Table 6. Chemical analysis of the evaluated broiler chicken breast and thigh/on-thigh in relation to the polyunsaturated FA (g.100 $\left.\mathrm{g}^{-1}\right)$.

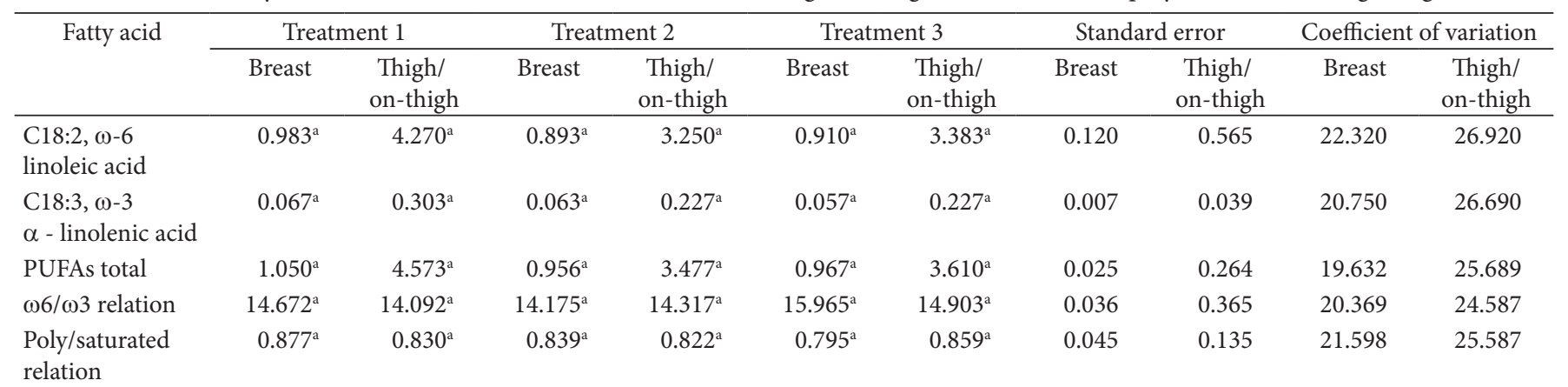

${ }^{\star}$ The values in the lines followed by different letters differ significantly among themselves according to the Tukey test ( $\left.\mathrm{p}<0.05\right)$; and ${ }^{\star *}$ the analyses are expressed on a dry matter basis.

tissue (LÓPEZ-FERRER et al., 2001; CORTINAS et al., 2004). Nevertheless, Hrdinka et al. (1996) observed a small relationship between the dietary content of PUFA and the percentage of these FAs in meat.

Regarding the ratio FAs $\omega 6 / \omega 3$ to chicken meat, no statistical difference between breast and thigh/ on-thigh treatments was noted. Despite that, the diet FAs' values presented meat contents way over the desired maximum because an appropriate use for both precursors was determined from the FAs.

(FOOD AND NUTRITION BOARD, 2005) in a relation to LA ( $\omega 6)$ :LNA $\omega 6)$ of 5:1 a 10:1 as recommended to human nutrition (FOOD AND AGRICULTURE ORGANIZATION AND WORLD HEALTH ORGANIZATION, 1994), which is necessary to compensate this deficiency with other food provided from diet rich in $\omega-3$. Regarding the PUFAs total and the relationship polyunsaturated/saturated, it could be observed that in breast as well as in thigh/on-thigh there was no statistical difference between the treatments.

Studies on chicken meat by Bragagnolo and RodriguezAmaya (1992) demonstrated that regarding PUFAs in white and red meat, the values were lower than the results obtained in this study. The authors found similar results for $\omega 6 / \omega 3$ in breast and lower results in chicken thigh. In studies evaluating cooked chicken meat related to FAs compositions (verified in skinless thigh), Souza et al. (1999) reported superior values of C18:2 and C18:3 and polyunsaturated/saturated relation compared to the control ration of this study. When skinless breasts were evaluated, they presented similar results of C18:2 and lower of $\mathrm{C} 18: 3$ and the polyunsaturated/saturated relation was way higher in thigh/on-thigh and lower in breast when compared to this study. The same authors ststed that among fatty acids PUFAs and the linoleic acid (C18:2, $\omega-6)$ presented higher amount in the thigh than in the breast, which is consistant with the findings of the present study.

In a study about the effect of barley inclusion (10\%) in broiler chicken diets, Nwokolo and Sim (1989) observed a linoleic and linolenic FAs significant increase $(\mathrm{p}<0.05)$ in the broiler chicken meat, which is not in agreement with the findings of this research. According to Newman et al. (2002) the polyunsaturated/saturated relation can be related to MUFAs diet percentage or to the specific ingestion of FAs. However, in this study, the poultry breast and thigh/on-thigh meat fed with barley contain equal MUFA statistical percentage than the other treatments, which probably shows that there are other metabolic influences in the storage of these FAs.

The results relative to the total saturated FAs quantity, MUFAs and PUFAs, in the samples analyzed were way higher than those shown in USDA Table (1999) both in the breast and in the thigh/on-thigh portions. Regarding breast, the TACO Table (2004) presents similar saturated FAs quantity; inferior values of MUFAs, and PUFAs are missing in this cut. Regarding thigh/on-thigh, the total saturated FAs quantity, MUFAs, and PUFAs present really lower values than those found in this research. This discrepancy in the results demonstrates a considerable variation among the analyses, diets, and evaluated animals, and is indicates that further studies in this area is necessary.

\section{Conclusions}

In general, it can be said that diets containing $20 \%$ of barley reduced the chicken meat quality, which can be noted by a decrease in the ash thigh values and an increase in the total saturated FAs in both breast and thigh/on-thigh.

The ration containing $10 \%$ of barley was efficient since it did not reduce any parameter in the control diet, but it decreased the concentration of myristic acid in the breast since this acid has great potential to increase the blood cholesterol.

The Food Composition Tables, both national and international, show discrepant values in the present study indicating the need for further studies related to the broiler chicken meat quality, mostly when one works with unconventional food on diet.

\section{Acknowledgments}

The authors are grateful to the Brazilian Agriculture Research Company - Embrapa Swines and Poultry, located in Concordia, SC, for its partnership in the chemical analyses, and to the Agrarian Industry of Entre Rios, for the donation of rations and chicks. 


\section{References}

AGRARIA - Cooperativa Agrária Mista Entre Rios. História da Agrária. Disponível em:<http://www.agraria.com.br/brasil/pagina. php?menu=comunicacao_noticia\&banner $=$ comunicacao\&com unicacao_noticia $=$ mostra_noticia\&idnoticia $=386>$. Acesso em: Dezembro 2007.

ANDERSON, J. W.; HANNA, T. J. Impact of nondigestible carbohydrates on serum lipoproteins and risk for cardiovascular disease. The Journal of Nutrition, v. 129, n. 7, p. 1475S-1466s, 1999.

Association of Official Analytical Chemistry - AOAC. Fat (Crude) or Ether Extract in Animal Feed. In: Official methods of analysis of AOAC international. 16 ed. Arlington, Virginia: Patricia Cunniff, 1995b. v. 1, cap. 4, p. 17.

Association of Official Analytical Chemistry - AOAC. Official Methods of Analysis. 16 ed. Arlington, VA, 1995.

Association of Official Analytical Chemistry - AOAC. Protein (Crude) in Animal Feed. In: Official methods of analysis of AOAC international. Method 976.06 G.H. 16 ed. Arlington, Virginia: Patricia Cunniff, 1995a. v. 1, cap. 4, p. 7-9.

BEHALL, K. M.; SCHOLFIELD, D. J.; HALLFRISCH, J. Diets containing barley significantly reduce lipids in mildly hypercholesterolemic men and women. American Journal Clinical of Nutrition, v. 80, n. 5, p. 1185-1193, 2004.

BERTOGLIO, O. Avicultura de corte brasileira: desempenho recente e competitividade internacional. Santa Maria, 2006. 176 p. Dissertação (Mestrado em Integração Latino-Americana.) Universidade Federal de Santa Maria - UFSM.

BOU, R. et al. Influence of dietary fat source, $\boldsymbol{\alpha}$-tocopherol, and ascorbic acid supplementation on sensory quality of dark chicken meat. Poultry Science, v. 80, n. 1, p. 1-8, 2001.

BRAGAGNOLO, N. Aspectos comparativos entre carnes segundo a composição de ácidos graxos e teor de colesterol. In: CONFERÊNCIA INTERNACIONAL VIRTUAL SOBRE QUALIDADE DE CARNE SUÍNA, 2, 2001, Campinas. Anais...

BRAGAGNOLO, N.; RODRIGUEZ-AMAYA, D. B. Teores de colesterol em carne de frango. Revista Farmácia Bioquímica, v. 28, n. 2, p. 122-131, 1992.

BRAGAGNOLO, N.; RODRIGUEZ-AMAYA, D. B. Teores de colesterol, lipídios totais e ácidos graxos em cortes de carne suína. Ciência e Tecnologia de Alimentos, v. 22, n. 1, p. 98-104, 2002.

BRUFAU, J.; PÉREZ-VENDRELL, A. M.; FRANCESCH, M. Papel de la fibra en la alimentación avícola. In: SIMPÓSIO DE AVICULTURA, SECCION ESPANOLA DE LA ASSOCIACION MUNDIAL DE AVICUlTURA CIENTÍfICA, 31, 1994, Pamplona. Anais... Pamplona, 1994. p.101-105.

BURGER, W. C. et al. Effects of Different Fractions of the Barley Kernel on the Hepatic Lipid Metabolism of Chickens. Lipids, v. 17, n. 12, p. 56-63, 1982.

CAMIRUAGA, M. et al. Respuesta productiva de pollos broilers a la adición de enzimas exógenas a dietas basadas en maíz o triticale. Ciência y Investigación Agraria, v. 28, n. 1, p. 23-36, 2001.

CHOUINARD, Y.; CORNEAU, L.; BARBANO, D. M. Conjugated linoleic acids alter milk fatty acid composition and inhibit milk fat secretion in dairy cows. The Journal of Nutrition, v. 129, n. 8, p. 1579-1584, 1999.

CORTINAS, L. et al. Fatty Acid Content in Chicken Thigh and Breast as Affected by Dietary Polyunsaturation Level. Poultry Science, v. 83, n. 7, p. 1155-1164, 2004.
CORTINAS, L. et al. Influencia del nivel de insaturación dietética sobre el depósito y efecto antioxidante del alfa-tocoferol en muslo de pollo (crudo, cocido y cocido-refrigerado). In: SYMPOSIUM CIENTÍFICO DE AVICULTURA. SECCIÓN ESPAÑOLA DE LA WPSA, 38, 2001, Córdoba, Spain. Proceedings... p. 141-148.

CRESPO, N.; ESTEVE-GARCIA, E. Dietary fatty acid profile modifiles abdominal fat deposition in broiler chickens. Poultry Science, v. 80, n. 1, p. 71-78, 2001.

DALE, N. Ingredient analysis table: 1996 edition. Feedstuffs, v. 68, n. 30, p. 24-31, 1996.

EMBRAPA. Alimentos para suínos. Boletim Informativo de Pesquisa Embrapa Suínos e Aves e Extensão, v. 8, n. 12, p. 1-61, 1999.

FARFAN, J. A. Alimentos que influenciam os níveis de colesterol no organismo. In: SEMINÁRIO "COLESTEROL": ANÁLISE, OCORRÊNCIA, REDUÇÃO EM ALIMENTOS E IMPLICAÇÕES NA SAÚDE. Anais... Campinas: ITAL, 1996.

FEED Industry Red Book: reference \& buyers guide. Chaska: ZMAG Publishing Inc., 1997. 208 p.

FERREIRA, D. F. Sistema de análise de variância - SISVAR. Versão 4.6. Lavras: UFLA, 1999.

FONSECA, R. A. Mejora de la utilización de la harina de raíz de mandioca en dietas avícolas mediante aplicación de enzimas. Zaragoza, 1996. 172 p. Tesis (Doctorado en Veterinaria) Universidad de Zaragoza - UNIZAR.

Food and Agriculture Organization and World Health Organization. Consultation on Fats and Oils. Fats and Oils in Human Nutrition. [S.L]: [s.n.], 1994. (FAO Food \& Nutrition Paper, n. 57, 1994).

FOOD and Nutrition Board. Dietary Reference Intakes for Energy, Carbohydrate, Fiber, Fat, Fatty Acids, Cholesterol, Protein, and Amino Acids. Washington, DC: The National Academies Press, 2005.

FRANCESCH, M.; PÉREZ-VENDRELL, A. M.; BRUFAU, J. Effects of cultivar, pelleting and enzyme addition on nutritive value of garley in poultry diets. British Poultry Science, v. 35, n. 2, p. 259-272, 1994.

GONZÁLEZ-ESQUERRA, R.; LEESON, S. Effects of menhaden oil and flaxseed in broiler diets on sensory quality and lipid composition of poultry meat. British Poultry Science, v. 41, n. 1, p. 481-488, 2000

GRAU, A. et al. Cholesterol oxidation in frozen dark chickenmeat: Influence of dietary fat source, and $\alpha$-tocopherol and ascorbic acid supplementation. Meat Science, v. 57, n. 2, p. 197-208, 2001 b.

GRAU, A. et al. Oxidative stability of dark chicken meat through frozen storage: Influence of dietary fat and $\alpha$-tocopherol and ascorbic acid supplementation. Poultry Science, v. 80, n. 11, p. 1630-1642, 2001a.

HARTMAN, L.; LAGO, R. C. A. Rapid preparation of fatty acids methyl esters. Laboratory Practice, v. 22, n. 6, p. 475-476, 1986.

HRDINKA, C. et al. Effects of dietary fatty acid pattern on melting point and composition of adipose tissues and intramuscular fat of broiler carcasses. Poultry Science, v. 75, n. 2, p. 208-215, 1996.

HULAN, H. W. et al. Omega-3 fatty acid levels and performance of broiler chickens fed redfish meal or redfish oil. Canadian Journal of Animal Science, v. 68, n. 2, p. 533-547, 1988.

HULBERT, A. J. et al. Dietary fats and membrane function: implications for metabolism and disease. Biological Reviews, v. 80, n. 1, p. 155-169, 2005. 
INSTITUTO ADOLFO LUTZ. Normas analíticas: Métodos químicos e físicos para análise de alimentos. São Paulo: Instituto Adolfo Lutz, 1985. v. 1, p. 23-58.

Instituto Brasileiro de Geografia e Estatística - IBGE. Levantamento sistemático da produção agrícola. Disponível em http:<//www. ibge.gov.br>. Acesso em: Março 2003.

JUNIOR, C. J. et al. A cadeia da carne de frango: tensões, desafios e oportunidades. BNDES Setorial, n. 26, p. 191-232, 2007.

KEYS, A.; ANDERSON, J. T.; GRANDE, F. Serum cholesterol response to changes in the diet. IV Particular Satured fatty acids in the diet. Metabolism, v. 14, n. 1, p. 776-780, 1965.

LADEIRA, M. M.; OLIVEIRA, R. L. Estratégias nutricionais para melhoria da carcaça bovina. In: SIMPÓSIO SOBRE DESAFIOS E NOVAS TECNOLOGIAS NA BOVINOCULTURA DE CORTE. SIMBOI, 2, 2006. Anais... Brasília: Faculdades Integradas - UPIS, 2006.

LAWRIE, R. A. Ciência da Carne. 6 ed. Porto Alegre: Artmed, 2004. $384 \mathrm{p}$.

LI, J. et al. Effects of fiber intake on the blood pressure, lipids, and heart rate. In: Goto Kakizaki rats. Nutrition, v. 20, n. 11/12, p. 1003-1007, 2004.

LOPEZ-BOTE, C. J. et al. Dietary vegetable oils and -a-tocopherol reduce lipid oxidation in rabbit muscle. Journal of Nutrition, v. 127, n. 6, p. 1176-1182, 1997.

LÓPEZ-FERRER, S. et al. N-3 enrichment of chicken meat. 1. Use of very long-chain fatty acids in chicken diets and their influence on meat quality: Fish oil. Poultry Science, v. 80, n. 6, p. 741-752, 2001.

MAHAN, L. K.; ARLIN, M. T. Alimentos, Nutrição e Dietoterapia. 11 ed. São Paulo: Roca, 2005. p. 38-40.

MIR, P. S. et al. Conjugated linoleic acid enriched beef production. American Journal of Clinical Nutrition, v. 79, n. 6, p. 1207s-1211s, 2004.

MOORE, M. A.; PARK, C. B.; TSUDA, H. Soluble and insoluble fiber influence on cancer development. Critical Review Oncology/ hematology, v. 27, n. 3, p.229-242, 1998.

NESTLÉ Nutrition Services. Tópicos em nutrição clínica: fibras em nutrição enteral, questões contemporâneas. [S.L.], 2000. 27 p.

NEVES, N. M. S. Nutrição e doença cardiovascular. Rio de Janeiro: Guanabara Koogan, 1997. 109 p.

NEWMAN, R. E. et al. Dietary n-3 and n-6 fatty acids alter avian metabolism: metabolism and abdominal fat deposition. British Journal of Nutrition, v. 88, n. 1, p. 11-18, 2002.

NWOKOLO, E.; SIM, J. Barley and full-fat canola seed in broiler diets. Poultry Science, v. 68, n. 10, p. 1374-1380, 1989.

PAN, D. A.; STORLIEN, L. H. Dietary lipid profile is a determinant of tissue phospholipid fatty acid composition and rate of weight gain in rats. Journal of Nutrition, v. 123, n. 3, p. 512-519, 1993.

PARIZA, M. W.; PARK, Y.; COOK, M. E. The biologically active isomers of conjugated linoleic acid. Progress in Lipid Research, v. 40, n. 4 , p. 283-298, 2001.

PEREZ, J. R. O. et al. Efeito do peso ao abate de cordeiros santa inês e bergamácia sobre o perfil de ácidos graxos, colesterol e propriedades químicas. Ciência e Tecnologia de Alimentos, v. 22, n. 1, p. 11-18, 2002.

PINOTTO, R. N.; ORINI e PAULILLO, L. F. de. A estruturação da rede de empresas processadoras de aves no estado de Santa Catarina: Governança contratual e dependência de recursos. Gestão e Produção, v. 13, n. 1, p. 167-177, 2006.
QURESHI, A. A. et al. Influence of culture filtrate of Trichoderma Viride and barley on lipid metabolism of laying hens. Lipids, v. 19, n. 4, p. 250-257, 1984.

QURESHI, A. A. et al. Regulation of lipid metabolism in chicken liver by dietary cereals. The Journal Nutrition, v. 110, n. 3, p. 388-393, 1980a.

QURESHI, A. A. et al. Regulation of lipid metabolism in chicken liver by dietary cereals supplemented with culture filtrate of Trichoderma viride. The Journal Nutrition, v. 110, n. 7, p. 1473-1478, 1980 b.

RAFAELLI, D. R. et al. Análise da qualidade quanto à acidez do óleo de frango utilizado para a fabricação de ração. Ciência e Agrotecnologia, v. 25, n. 3, p. 641-645, 2001.

RATNAYAKE, W. M. N.; ACKMAN, R. G.; HULAN, H. W. Effect of redfish meal enriched diets on the taste and n-3PUFA of 42-day-old broiler chickens. Journal of The Science of Food and Agriculture, v. 49, n. 1, p. 59-74, 1989.

ROSTAGNO, H. S. et al. Tabelas brasileiras para aves e suínos: composição de alimentos e exigências nutricionais. Viçosa: Universidade Federal de Viçosa, 2000. 60 p.

RUBERFROID, M. Dietary fiber, inulin and oligofrutose: a revewcomparing their phisiological efects. Critical Review of Food Science Nutrition, v. 33, n. 6, p. 1303-1348, 1993.

SANTINI, G. A. et al. Inovações tecnológicas em cadeias agroindustriais: alguns casos do segmento de processamento de carnes, leite e café. Gestão da Produção, Operações e Sistemas - GEPROS, v. 1, n. 3, p. 1-13, 2006.

SANZ, M. et al. Abdominal fat deposition and fatty acid synthesis are lower and $\beta$-oxidation is higher in broiler chickens fed diets containing unsaturated rather than saturated fat. Journal of Nutrition, v. 130, n. 12, p. 3034-3037, 2000.

SOUZA, S. A. B. et al. Lipids and fatty acids in roasted chickens. Archivos Latinoamericanos de Nutrición, v. 4, n. 3, p. 295-297, 1999.

SOUZA-SOARES, L. A.; SIEWERDT, F. Aves e ovos. Pelotas: UFPEL, 2005. $138 \mathrm{p}$.

TORRES, D. M. Valor nutricional de farelos de arroz suplementados com fitase, determinado por diferentes metodologias com aves. Lavras, 2003. 172 p. Tese (Doutorado em Zootecnia) - Universidade Federal de Lavras - UFLA.

TORRES, E. A. F. S. et al. Composição centesimal e valor calórico de alimentos de origem animal. Ciência e Tecnologia de Alimentos, v. 20, n. 2, p. 145-150, 2000.

UNICAMP. Tabela Brasileira de Composição de Alimentos - TACO. Campinas: NEPA, 2004. 114 p.

United States Department of Agriculture - USDA. NDB n.10199. Nutrient data base for standard reference. Released 13. EUA, 1999.

Van HEERDEN, S. M. et al. Nutrient Content of South African Chickens. Journal of Food Composition and Analysis, v. 15, n. 1, p. 47-64, 2002.

VILLAVERDE, C. et al. Total fatty acid quantification as an estimator of total body fat content in broilers fed unsaturated diets. In: EUROPEAN SYMPOSIUM ON THE QUALITY OF POULTRY MEAT, 16, 2003, France. Proceedings...

ZARDO, A. O.; LIMA, G. J. M. M. Alimentos para suínos. Boletim Informativo de Pesquisa - Embrapa Suínos e Aves e Extensão, Ano. 8, n. 12, 1999. 